\title{
Reduction of proteolysis of high protein silage from Moringa and Indigofera leaves by addition of tannin extract
}

\author{
Anuraga Jayanegara, Aldi Yaman and Lilis Khotijah \\ Department of Nutrition and Feed Technology, Faculty of Animal Science, Bogor Agricultural University, Bogor 16680, \\ Indonesia. \\ Corresponding author: Anuraga Jayanegara, e-mail: anuraga.jayanegara@gmail.com \\ Co-authors: AY: aldiyaman@gmail.com, LK: lilis.khotijah@gmail.com \\ Received: 07-09-2018, Accepted: 21-12-2018, Published online: 09-02-2019
}

doi: 10.14202/vetworld.2019.211-217 How to cite this article: Jayanegara A, Yaman A, Khotijah L (2019) Reduction of proteolysis of high protein silage from Moringa and Indigofera leaves by addition of tannin extract. Veterinary World, 12(2): 211-217.

\begin{abstract}
Aim: The objective of this experiment was to evaluate the effect of the addition of tannin extract to Moringa and Indigofera leaf silages on their chemical composition, silage quality characteristics, and in vitro rumen fermentation parameters and digestibility.

Materials and Methods: Moringa and Indigofera leaves were cut ( $3 \mathrm{~cm}$ length) and added with either 0, 2, or 4\% chestnut tannin in three replicates. The leaves were then inserted into lab-scale silos (1 L capacity) and kept for 30 days. Silage samples were subjected to silage quality determination, chemical composition analysis, and in vitro rumen fermentation and digestibility evaluation using a gas production technique. Data obtained were subjected to the analysis of variance with a factorial statistical model in which the first factor was different silage species and the second factor was tannin addition levels.

Results: Tannin addition at 4\% dry matter (DM) increased neutral detergent insoluble crude protein (NDICP) and acid detergent insoluble CP (ADICP) of Indigofera silage. A similar response was observed in Moringa silage, but it required less tannin, i.e., $2 \%$ DM to increase its NDICP and ADICP. Moringa silage had lower $\mathrm{pH}$ than that of Indigofera silage ( $\mathrm{p}<0.05)$, and tannin addition did not change $\mathrm{pH}$ of both Indigofera and Moringa silages. Higher addition level of tannin decreased total volatile fatty acid (VFA) and ammonia concentrations of both Indigofera and Moringa silages $(\mathrm{p}<0.05)$. A higher level of tannin addition reduced ruminal total VFA concentration, ammonia, in vitro DM digestibility, and in vitro organic matter digestibility of Indigofera and Moringa silages $(p<0.05)$. Tannin addition also decreased ruminal methane emission of both Indigofera and Moringa silages $(\mathrm{p}<0.05)$.
\end{abstract}

Conclusion: Tannin extract can reduce proteolysis of high protein silage from Moringa and Indigofera leaves.

Keywords: deamination, feed fermentation, polyphenol, protein degradation.

\section{Introduction}

Indigofera and Moringa leaves are known to have high protein contents and therefore have been used as protein supplements in ruminant diets [1-4]. These forages are typically used either as fresh or dried forms. Another possible way to use Indigofera and Moringa leaves is through anaerobic fermentation of the forages by the action of primarily lactic acid bacteria [5], i.e., their silage forms. Use of Indigofera and Moringa leaves in their conserved forms as silages is a way to provide sufficient protein supply continuously across all seasons in a year. However, such high protein silages have a problem with regard to massive protein degradation and amino acids deamination during the ensiling process $[6,7]$. Our previous study

Copyright: Jayanegara, et al. Open Access. This article is distributed under the terms of the Creative Commons Attribution 4.0 International License (http://creativecommons.org/licenses/ by/4.0/), which permits unrestricted use, distribution, and reproduction in any medium, provided you give appropriate credit to the original author(s) and the source, provide a link to the Creative Commons license, and indicate if changes were made. The Creative Commons Public Domain Dedication waiver (http:// creativecommons.org/publicdomain/zero/1.0/) applies to the data made available in this article, unless otherwise stated. showed that Indigofera and Moringa leaf silages had high $\mathrm{pH}$ values and high ammonia concentrations that contributed to their low silage quality [8]. It had been recommended that a certain silage additive is necessary to prevent or to minimize such considerable proteolysis in high protein silages. Ideally, the additive provides additional advantages other than its function in silage.

Here, we attempted to use tannin extract as a silage additive. Tannin has multiple hydroxyl groups in its structure and ability to interact with other molecules particularly protein [9] and therefore is expected to protect microbial degradation of protein occurring in silage. Apart from its potential use as a silage additive, tannin has been reported to provide additional benefits when being used in the diet of ruminants. Tannin is able to protect protein degradation by rumen microbes [10] thus enhances protein bypass and metabolizable protein supply for ruminants [11], and in turn, improves animal productivity [12]. Parasitic nematodes can be controlled by tannin in the digestive tract of ruminants [13]. Further, tannin reduces enteric methane emission of ruminants through inhibition of methanogen and protozoa population [14]. Tannin 
inhibits biohydrogenation of polyunsaturated fatty acids in the rumen [15] and improves the deposition of these beneficial fatty acids in animal products $[16,17]$.

This study aimed to evaluate the effect of the addition of tannin extract to Moringa and Indigofera leaf silages on their chemical composition, silage quality characteristics, and in vitro rumen fermentation parameters, and digestibility. It was hypothesized that tannin extract would limit proteolysis occurring in Moringa and Indigofera silages.

\section{Materials and Methods}

\section{Ethical approval}

The present experiment used rumen content (both solid and liquid parts) as the source of microbial inoculum. Rumen content was collected from two fistulated Ongole crossbred cattle before morning feeding, located at Biotechnology Research Center, Indonesian Institute of Sciences, Bogor, Indonesia. The cattle were maintained according to the animal welfare standard of Indonesian Institute of Sciences. Approval of the whole experiment was granted from the Faculty of Animal Science, Bogor Agricultural University, Indonesia.

\section{Sample collection and ensiling procedure}

Moringa and Indigofera leaves were collected from Agrostology Field Laboratory of Faculty of Animal Science, Bogor Agricultural University. Approximately $9 \mathrm{~kg}$ fresh of each leaf species was manually cut ( $3 \mathrm{~cm}$ length) and divided into nine portions. Each portion was added with either 0, 2, or 4\% chestnut tannin (dry matter [DM] basis) in three replicates. Leaves were then inserted into lab-scale silos (1 L capacity) and kept for 30 days. Each lab-scale silo is equipped with a slit that enables gas formed during ensiling to escape but prevents gas from outside to enter the silo. After 30 days, the silo was opened, and silage was divided into two portions with a similar proportion. The first portion was mixed with distilled water in a blender (silage: distilled water 1:7, $\mathrm{w} / \mathrm{w}$ [18]) and the supernatant was subjected to silage quality determination. The second portion was ovendried at $60^{\circ} \mathrm{C}$ for $24 \mathrm{~h}$, ground by a hammer mill to pass a $1 \mathrm{~m}$ sieve, and used for chemical composition analysis and in vitro rumen fermentation evaluation.

\section{Chemical composition analysis}

Silage samples were determined for their chemical constituents, i.e., DM, crude protein (CP), neutral detergent fiber (NDF), acid detergent fiber (ADF), neutral detergent insoluble $\mathrm{CP}$ (NDICP), and acid detergent insoluble $\mathrm{CP}$ (ADICP). DM was determined by oven-drying the sample at $105^{\circ} \mathrm{C}$ for $24 \mathrm{~h}$, whereas $\mathrm{CP}$ was analyzed using a Micro Kjeldahl Apparatus to obtain $\mathrm{N}$ content [19]. The CP was obtained by multiplying $\mathrm{N}$ content with 6.25 , assuming that generally, protein contains $16 \% \mathrm{~N}$. Contents of NDF and ADF were determined according to Van Soest et al. [20]. Briefly, an amount of $1 \mathrm{~g}$ sample was put into a $600 \mathrm{ml}$ beaker glass and added with $100 \mathrm{ml}$ neutral detergent solution, and boiled for $60 \mathrm{~min}$. The residue was separated from supernatant through filtration using a crucible and regarded as NDF. Determination of ADF was similar to that of NDF except that the solution used was an acid detergent solution. The NDF and ADF values were expressed exclusive of residual ash. For NDICP and ADICP determinations, the NDF and $\mathrm{ADF}$ residues were further analyzed for their $\mathrm{CP}$ contents, respectively [21]. Determination of these chemical constituents was performed in duplicate.

\section{Silage quality determination}

The supernatant obtained after the ensiling procedure was determined for $\mathrm{pH}$, total volatile fatty acid (VFA) concentration and ammonia concentration. Measurement of silage $\mathrm{pH}$ was conducted using a $\mathrm{pH}$ meter. Determination of total VFA concentration was according to the steam distillation method whereas ammonia was determined by employing a Conway microdiffusion method as described by Jayanegara et al. [22].

\section{In vitro rumen fermentation}

Ground silage samples were subjected to in vitro incubation with rumen fluid: buffer mixture [23]. Briefly, an amount of $0.75 \mathrm{~g}$ of each silage sample was inserted into an incubation bottle (125 ml capacity) and then was added $75 \mathrm{ml}$ rumen fluid: buffer mixture that comprised $15 \mathrm{ml}$ rumen fluid and $60 \mathrm{ml}$ buffer. All bottles were saturated with $\mathrm{CO}_{2}$ to maintain anaerobic condition before in vitro incubation. Bottles were closed with rubber caps and aluminum seals to start the incubation. Incubation was done in a water bath at a constant temperature of $39^{\circ} \mathrm{C}$ for $72 \mathrm{~h}$. Gas production was vented and recorded at 2, 4, 6, 8, 10, $12,24,36,48$, and $72 \mathrm{~h}$ after incubation using a plastic syringe (equipped with a needle) with a volume of $50 \mathrm{ml}$. Manual shaking was performed to all bottles shortly after gas production measurement. Methane gas production was determined at each gas production measurement according to Fievez et al. [24].

Another set of bottles that received similar samples was incubated for $24 \mathrm{~h}$ for determination of rumen fermentation and digestibility parameters. Solid and supernatant parts in each incubation bottle were separated using a centrifuge. The resulting supernatant was subjected to analysis of total VFA and ammonia concentration as described above, similar to that of silage quality determination. The solid part was incubated again with $75 \mathrm{ml}$ of pepsin- $\mathrm{HCl} 0.2 \mathrm{~N}$ solution for another $24 \mathrm{~h}$. After the second incubation, the residue was filtered using a filter paper under vacuum. It was then dried in an oven at $105^{\circ} \mathrm{C}$ for $24 \mathrm{~h}$ and subsequently put in a furnace at $500^{\circ} \mathrm{C}$ for $4 \mathrm{~h}$ to obtain DM and $\mathrm{OM}$ weight of the residue, respectively. In vitro DM digestibility (IVDMD) and in vitro organic matter digestibility (IVOMD) were calculated by the difference between initial DM and OM weight before incubation and final DM and OM weight after the two-stage in vitro incubation, respectively [25]. The 
in vitro incubation was performed in three replicates and allocation of samples into experimental units followed a randomized complete block design.

\section{Statistical analysis}

Data obtained were subjected to analysis of variance with a factorial statistical model in which the first factor was different silage species (Indigofera and Moringa) and the second factor was tannin addition levels $(0,2$, and $4 \% \mathrm{DM})$. Any significant effects of the treatments, either main factors or their interaction, were continued with a post hoc test, namely Duncan's multiple range test. These statistical analyses were conducted using SAS software version 9.1. For data on chemical composition only, silage samples from three replicates were pooled into one and were analyzed in duplicate; therefore, the data were presented descriptively.

\section{Results}

\section{Chemical composition and silage quality}

$\mathrm{CP}$ contents of Indigofera and Moringa silages were comparable, i.e., slightly above $30 \%$, expressed on a DM basis (Table-1). Contents of NDF, ADF, NDICP, and ADICP of Moringa silage were lower in comparison to Indigofera silage. Addition of tannin extract up to $4 \% \mathrm{DM}$ did not change NDF and ADF contents of Indigofera and Moringa silages. Tannin addition at $4 \%$ increased NDICP and ADICP of Indigofera silage. A similar response was observed in Moringa silage, but it required less tannin, i.e., $2 \%$ to increase its NDICP and ADICP.
Loss of DM was similar between Indigofera and moringa during ensiling either without or with tannin extract addition (Table-2). Moringa silage had lower $\mathrm{pH}$ than that of Indigofera silage $(\mathrm{p}<0.05)$, and tannin addition did not change $\mathrm{pH}$ of both Indigofera and moringa silages. Indigofera silage produced higher total VFA and ammonia concentrations as compared to Moringa silage $(p<0.05)$. Higher addition level of tannin decreased total VFA and ammonia concentrations of both Indigofera and Moringa silages $(p<0.05)$.

\section{In vitro rumen fermentation and digestibility}

In vitro gas production of Moringa silage was higher than that of Indigofera silage at $12 \mathrm{~h}$ incubation period $(\mathrm{p}<0.05)$, but it turned to be similar for $24 \mathrm{~h}$ and after (Table-3). Addition of tannin extract decreased in vitro gas production of both Indigofera and Moringa silages $(\mathrm{p}<0.05)$. A higher level of tannin addition reduced ruminal total VFA concentration, ammonia, IVDMD and IVOMD of Indigofera and Moringa silages $(\mathrm{p}<0.05$; Table-4). The interaction between forage $\times$ tannin was significant for total VFA $(p<0.05)$, indicating that the magnitude of decrease of the parameter was different between the two forages with increasing level of tannin addition. Addition of 2 and 4\% tannin decreased ruminal total VFA concentration of Indigofera silage by 11.9 and $35.1 \%$, respectively, whereas the decrease was 23.6 and $41.7 \%$ for Moringa silage, respectively. Tannin addition also decreased ruminal methane emission of both Indigofera and Moringa silages $(\mathrm{p}<0.05)$, but the emission was similar between them (Figure-1).

Table-1: Chemical composition of Indigofera and Moringa leaf silage with different level of chestnut tannin addition.

\begin{tabular}{|c|c|c|c|c|c|c|}
\hline Forage & Tannin (\%DM) & CP (\%DM) & NDF (\%DM) & ADF (\%DM) & NDICP (\%CP) & ADICP (\%CP) \\
\hline \multirow[t]{3}{*}{ Indigofera } & 0 & 31.7 & 24.3 & 21.1 & 11.0 & 6.1 \\
\hline & 2 & 31.7 & 23.7 & 21.1 & 11.1 & 6.1 \\
\hline & 4 & 31.7 & 23.4 & 21.3 & 12.6 & 9.4 \\
\hline \multirow[t]{3}{*}{ Moringa } & 0 & 30.2 & 20.7 & 13.6 & 7.4 & 5.4 \\
\hline & 2 & 30.9 & 19.7 & 13.4 & 9.0 & 6.2 \\
\hline & 4 & 30.6 & 19.4 & 13.7 & 9.3 & 6.4 \\
\hline
\end{tabular}

$\mathrm{ADF}=$ Acid detergent fiber, $\mathrm{ADICP}=$ Acid detergent insoluble crude protein, $\mathrm{CP}=$ Crude protein, $\mathrm{DM}=$ Dry matter, $\mathrm{NDF}=$ Neutral detergent fiber, $\mathrm{NDICP}=$ Neutral detergent insoluble crude protein

Table-2: Fermentation characteristics of Indigofera and Moringa leaf silage with different level of chestnut tannin addition.

\begin{tabular}{|c|c|c|c|c|c|c|}
\hline Forage & Tannin (\%DM) & DM (\%) & DM loss (\%) & pH & VFA (mmol/l) & $\mathrm{NH}_{3}(\mathrm{mmol} / \mathrm{I})$ \\
\hline \multirow[t]{3}{*}{ Indigofera } & 0 & 20.1 & 1.56 & $5.37^{c}$ & $153^{d}$ & $13.0^{c}$ \\
\hline & 2 & 20.1 & 2.07 & $5.27^{\mathrm{bc}}$ & $143^{c}$ & $10.5^{\mathrm{bc}}$ \\
\hline & 4 & 20.7 & 2.04 & $5.57^{c}$ & $138^{\mathrm{bc}}$ & $8.4^{\mathrm{ab}}$ \\
\hline \multirow[t]{3}{*}{ Moringa } & 0 & 20.1 & 1.49 & $5.00^{\mathrm{ab}}$ & $138^{\mathrm{bc}}$ & $10.9^{\mathrm{bc}}$ \\
\hline & 2 & 20.1 & 4.55 & $4.97^{a b}$ & $129^{b}$ & $8.4^{a b}$ \\
\hline & 4 & 20.5 & 2.83 & $4.87^{a}$ & $116^{a}$ & $6.0^{\mathrm{a}}$ \\
\hline SEM & & 0.254 & 0.368 & 0.070 & 3.12 & 0.610 \\
\hline \multicolumn{7}{|l|}{ p-value } \\
\hline Forage & & 0.941 & 0.119 & $<0.001$ & $<0.001$ & 0.006 \\
\hline Tannin & & 0.692 & 0.112 & 0.647 & $<0.001$ & $<0.001$ \\
\hline Foragextannin & & 0.989 & 0.287 & 0.178 & 0.545 & 0.976 \\
\hline
\end{tabular}

Different superscripts within the same column are statistically different at $\mathrm{p}<0.05$. DM=Dry matter, $\mathrm{NH}_{3}=\mathrm{Ammonia}_{\text {, }}$ SEM=Standard error of mean, VFA=Volatile fatty acid 
Table-3: In vitro gas production at a various incubation period of Indigofera and Moringa leaf silage with different level of chestnut tannin addition.

\begin{tabular}{|c|c|c|c|c|c|c|}
\hline \multirow[t]{2}{*}{ Forage } & \multirow{2}{*}{$\frac{\text { Tannin }}{\text { (\%DM) }}$} & \multicolumn{5}{|c|}{ Gas production (ml) } \\
\hline & & $12 \mathrm{~h}$ & $24 \mathrm{~h}$ & $36 \mathrm{~h}$ & $48 \mathrm{~h}$ & $72 \mathrm{~h}$ \\
\hline \multirow{3}{*}{ Indigofera } & 0 & $61^{b c}$ & $88^{c}$ & $98^{c}$ & $103^{c}$ & $108^{c}$ \\
\hline & 2 & $57^{b}$ & $83^{b c}$ & $95^{\mathrm{bc}}$ & $100^{\mathrm{bc}}$ & $105^{\mathrm{abc}}$ \\
\hline & 4 & $44^{a}$ & $72^{a}$ & $89^{a}$ & $95^{\mathrm{ab}}$ & $100 a$ \\
\hline \multirow[t]{3}{*}{ Moringa } & 0 & $70^{d}$ & $87^{c}$ & $97^{c}$ & $101^{\mathrm{c}}$ & $107^{b c}$ \\
\hline & 2 & $64^{\text {cd }}$ & $82^{b c}$ & $92^{\mathrm{abc}}$ & $99 a b c$ & $106^{a b c}$ \\
\hline & 4 & $61^{b c}$ & $79^{b}$ & $90^{\mathrm{ab}}$ & $94^{a}$ & $101^{\mathrm{ab}}$ \\
\hline $\begin{array}{l}\text { SEM } \\
\text { p-value }\end{array}$ & & 1.709 & 1.248 & 1.012 & 1.154 & 1.008 \\
\hline Forage & & $<0.001$ & 0.378 & 0.517 & 0.480 & 0.999 \\
\hline Tannin & & $<0.001$ & $<0.001$ & 0.001 & 0.004 & 0.016 \\
\hline Forage $\times$ tannin & & 0.119 & 0.147 & 0.699 & 0.993 & 0.970 \\
\hline
\end{tabular}

Different superscripts within the same column are statistically different at $p<0.05$. DM=Dry matter; SEM=Standard error of mean

Table-4: In vitro rumen fermentation and digestibility of Indigofera and Moringa leaf silage with different level of chestnut tannin addition.

\begin{tabular}{|c|c|c|c|c|c|}
\hline Forage & Tannin (\%DM) & VFA $(\mathrm{mmol} / \mathrm{l})$ & $\mathrm{NH}_{3}(\mathrm{mmol} / \mathrm{I})$ & IVDMD (\%) & IVOMD (\%) \\
\hline \multirow{3}{*}{ Indigofera } & 0 & $134^{f}$ & $25.2^{\mathrm{d}}$ & $70.0^{c}$ & $67.8^{d}$ \\
\hline & 2 & $118^{\mathrm{d}}$ & $16.9^{c}$ & $66.3^{b}$ & $64.2^{\mathrm{bc}}$ \\
\hline & 4 & $87^{b}$ & $15.0^{\mathrm{ab}}$ & $62.9^{a}$ & $60.4^{a}$ \\
\hline \multirow[t]{3}{*}{ Moringa } & 0 & $127^{e}$ & $24.7^{\mathrm{d}}$ & $69.8^{c}$ & $66.3^{\text {cd }}$ \\
\hline & 2 & $97^{c}$ & $15.8^{\mathrm{bc}}$ & $68.2^{\mathrm{bc}}$ & $64.4^{\mathrm{bc}}$ \\
\hline & 4 & $74^{a}$ & $13.4^{\mathrm{a}}$ & $66.2^{\mathrm{b}}$ & $62.5^{\mathrm{ab}}$ \\
\hline $\begin{array}{l}\text { SEM } \\
\text { p-value }\end{array}$ & & 3.82 & 0.832 & 0.519 & 0.545 \\
\hline Forage & & $<0.001$ & 0.041 & 0.010 & 0.713 \\
\hline Tannin & & $<0.001$ & $<0.001$ & $<0.001$ & $<0.001$ \\
\hline Foragextannin & & 0.040 & 0.677 & 0.087 & 0.132 \\
\hline
\end{tabular}

Different superscripts within the same column are statistically different at $\mathrm{p}<0.05$. DM=Dry matter, IVDMD=In vitro dry matter digestibility, IVOMD $=$ In vitro organic matter digestibility, $\mathrm{NH}_{3}=$ Ammonia, $\mathrm{SEM}=$ Standard error of mean, VFA=Volatile fatty acid

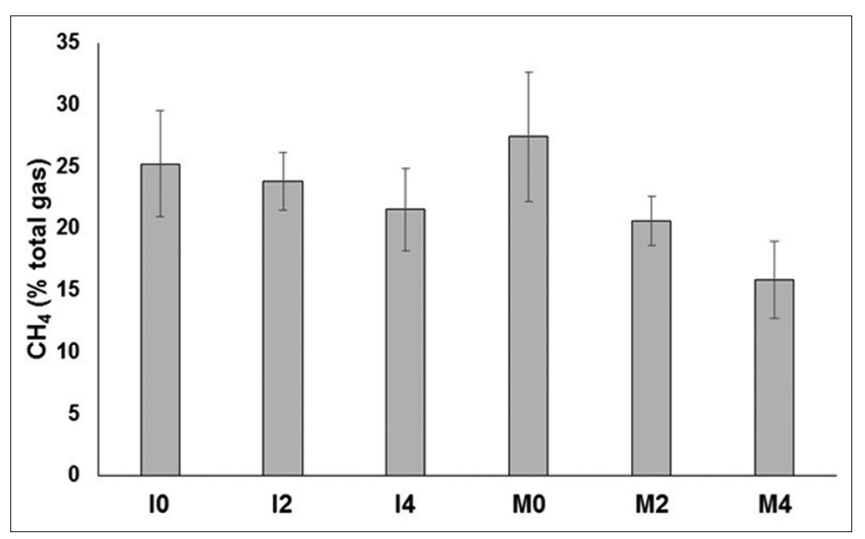

Figure-1: In vitro methane concentration (\% total gas) of Indigofera and Moringa leaf silage with different level of chestnut tannin addition. I0, Indogofera leaf silage; I2, Indogofera $+2 \%$ chestnut tannin; I4, Indogofera $+4 \%$ chestnut tannin; M0, Moringa leaf silage; M2, Moringa $+2 \%$ chestnut tannin; M4, Moringa $+4 \%$ chestnut tannin. p: forage $=0.282$, tannin $=0.027$, forage $\times \operatorname{tannin}=0.300$. Error bar indicates standard error for each treatment.

\section{Discussion}

Chemical composition and silage quality

High CP contents observed in Indigofera and Moringa silages confirm their potency to be used as protein supplements in ruminant diets as also reported by other authors $[1,2]$. Tannin extract addition does not alter CP contents of the silages, but it increases NDICP and ADICP proportions to total CP. During ensiling, protein is degraded into various peptides and amino acids with lower molecular weights and more soluble [6]. The NDICP and ADICP are insoluble CP in neutral and acid detergent solutions, respectively, and tannin apparently prevents their degradation. Although tannin may also interact with fiber components, the unchanged NDF and ADF contents of the silages indicate its lower affinity as compared to tannin-protein interaction. In agreement to the present results, Adesogan and Salawu [26] observed that addition of quebracho tannin at $16 \mathrm{~g} / \mathrm{kg}$ fresh weight of high pea (pea/wheat 3:1) and low pea (pea/wheat 1:3) bi-crop silages did not alter their NDF contents. Similarly, the NDF and ADF contents of perennial ryegrass silage were similar between control and the one added with mimosa tannin at $75 \mathrm{~g} / \mathrm{kg}$ forage DM [27].

The generally high $\mathrm{pH}$ values observed in Moringa and Indigofera silages are apparently related to their high CP contents. Forages containing high 
CP like legumes possess higher buffering capacity as compared to low CP forages like grasses [28]. While grass silage may reach $\mathrm{pH}$ value around 4.0 or less [27,29], it is normally hard for legume silage to obtain a $\mathrm{pH}$ value of 4.5 or less [30]. Lower $\mathrm{pH}$ found in Moringa silage as compared to that of Indigofera is apparently related to its lower NDF and ADF contents. This indicates that Moringa silage contains more readily available and fermentable carbohydrate to result in more lactic acid concentration that contributes to lower $\mathrm{pH}$ value. It has been widely known that a primary factor determining silage quality is the concentration of readily available or water-soluble carbohydrate (WSC). Lactic acid bacteria proliferate and utilize WSC to produce lactic acid [31]. As the lactic acid is produced and increases in concentration, it decreases $\mathrm{pH}$ of the silage below a certain critical point to prevent the growth of undesired or spoilage microbes [32].

Higher ammonia concentration of Indigofera silage as compared to that of Moringa silage is apparently related to its slightly higher CP content. A lower concentration of ammonia by addition of tannin is possible since tannin protects plant protein from microbial degradation and fermentation during ensiling. Free phenolic groups present in tannin enable the compound to form tannin-protein complexes [33]. Tannin may also bind to enzyme released by proteolytic microbes in silage and therefore reduce their activity [26]. In agreement with the present finding, Ding et al. [34] observed that addition of tannic acid, a simple form of tannin, decreased ammonia nitrogen, non-protein nitrogen, and amino acid concentrations in alfalfa silage.

Further, in a recent meta-analysis study, it was revealed that addition of tannin extracts (from various sources) lowered concentrations of butyric acid, soluble nitrogen, non-protein nitrogen and ammonia nitrogen of silages, and tended to reduce free amino acid concentration [35]. From these facts, it is apparently evident that addition of tannin to high protein silages may lower the extent and rate of proteolysis during ensiling and therefore improve their quality.

\section{In vitro rumen fermentation and digestibility}

Higher in vitro gas production of moringa silage than that of Indigofera during early incubation hours seems to be caused by its higher fermentable carbohydrate. This is indicated by the lower NDF and ADF contents of Moringa silage as compared to Indigofera silage. Gas in the in vitro rumen incubation system is produced by nutrient degradation and fermentation, particularly carbohydrate. Although protein fermentation also contributes to gas production, it stoichiometrically produces considerable gas in comparison to carbohydrate, whereas the contribution of fat to gas production is negligible [36]. Therefore, extent and rate of gas production are primarily determined by content and type of carbohydrate present in the substrate. Accordingly, Krieg et al. [37] investigated in vitro ruminal fermentation of grains from different rye, triticale, and barley genotypes. The authors observed that, supporting the current study, starch concentrations in these grains were positively correlated with gas production measured at $24 \mathrm{~h}$ after incubation, potential gas production, and gas production rate. Conversely, their NDF and ADF concentrations were negatively correlated with potential gas production and gas production rate.

Lower in vitro gas production, ruminal total VFA, ammonia concentration, IVDMD, and IVOMD of both Indigofera and Moringa silages at the increasing level of tannin addition indicate that the compound reduces rumen fermentation. Such responses are possible due to the interaction between tannin with macromolecules particularly protein and carbohydrate as described above, thus protecting their degradation and fermentation in the rumen. VFA and ammonia in the rumen are fermentation products of mainly carbohydrate and protein, respectively [38,39]. Confirming the results obtained, a number of studies have reported negative correlations between tannin and total VFA, ammonia concentration, or in vitro digestibility [40-42]. Despite such facts, the presence of tannin under ruminal environment does not always mean negative with regard to its effect on animal performance. Tannin protects protein in the rumen [10], increases proportion of rumen undegradable protein [43], increases supply of metabolizable protein for the host animal [11], and enhances animal production performance $[12,44]$.

Although tannin is added for conserving protein and thus improving silage quality, its effect on mitigating ruminal methane emission is obvious. Methane mitigating effect of tannin is possible since tannin has been shown to decrease the methanogen population, the microbial group responsible for methanogenesis. Jayanegara et al. [45] observed that addition of purified tannins from chestnut, sumach, mimosa, or qu bracho at $1 \mathrm{mg} / \mathrm{ml}$ addition level decreased methanogen population in the rumen in vitro. The methanogen population after such addition became 63.3$77.7 \%$ from the population in the control treatment (without purified tannin addition). Further, tannin may also reduce protozoa population whereby part of the methanogen lives in symbiosis with the fauna. Bhatta et al. [14] reported that increasing tannin concentration from $0 \%$ to $25 \%$ of total mixed ration (DM basis) linearly decreased protozoa population. Apart from its antimicrobial activity on methanogen and protozoa in the rumen, tannin decreases hydrogen production, the main substrate for methanogenesis through the reduction in nutrient degradation particularly fiber. This was indicated by the lower IVDMD, and IVOMD observed in the present study. It had been demonstrated that incubation of Lotus pedunculatus (containing condensed tannin) produced hydrogen by approximately $50 \%$ as compared to that of Medicago sativa (no tannin) [46]. Tannin may also serve as a hydrogen sink that competes with methane formation [47]. 


\section{Conclusion}

Tannin extract can reduce proteolysis of high protein silage from Moringa and Indigofera leaves. Therefore, the natural compound is promising to be used as a silage additive particularly when the ensiled material is rich in protein. Tannin retains its biological activity during ensiling and thus may provide additional benefits when being used in silage, i.e., as a protein by-pass and methane-mitigating agents. Further, in vivo experiments are required to observe the effects of tannin addition in silage on animal production performance.

\section{Authors' Contributions}

$\mathrm{AJ}$ designed and supervised the experiment, analyzed the data, drafted, and revised the manuscript. AY performed the experiment and collected the data. LK supervised the experiment and revised the manuscript. All authors read and approved the final manuscript.

\section{Acknowledgment}

This research is funded by Indonesian Ministry of Research, Technology, and Higher Education through "Program Penelitian Berbasis Kompetensi," year 2018, contract number 129/SP2H/PTNBH/ $\mathrm{DRPM} / 2018$.

\section{Competing Interests} interests.

The authors declare that they have no competing

\section{Publisher's Note}

Veterinary World remains neutral with regard to jurisdictional claims in published institutional affiliation.

\section{References}

1. Kholif, A.E., Gouda, G.A., Morsy, T.A., Salem, A.Z.M., Lopez, S. and Kholif, A.M. (2015) Moringa oleifera leaf meal as a protein source in lactating goat's diets: Feed intake, digestibility, ruminal fermentation, milk yield and composition, and its fatty acids profile. Small Rum. Res., 129: 129-137.

2. Suharlina, A.D.A., Nahrowi, J.A. and Abdullah, L. (2016) Nutritional evaluation of dairy goat rations containing Indigofera zollingeriana by using in vitro rumen fermentation technique (RUSITEC). Int. J. Dairy Sci., 11(3): 100-105.

3. Jadhav, R.V., Chaudhary, L.C., Agarwal, N. and Kamra, D.N (2018) Influence of Moringa oleifera foliage supplementation on feed intake, rumen fermentation and microbial profile of goats. Indian J. Anim. Sci., 88(4): 458-462.

4. Tarigan, A., Ginting, S.P., Arief, I.I., Astuti, D.A. and Abdullah, L. (2018) Body weight gain, nutrients degradability and fermentation rumen characteristics of Boerka goat supplemented green concentrate pellets (GCP) based on Indigofera zollingeriana. Pak. J. Biol. Sci., 21(2): 87-94.

5. Bernardes, T.F., Daniel, J.L.P., Adesogan, A.T., McAllister, T.A., Drouin, P., Nussio, L.G., Huhtanen, P., Tremblay, G.F., Bélanger, G. and Cai, Y. (2018) Silage review: Unique challenges of silages made in hot and cold regions. J. Dairy Sci., 101(5): 4001-4019.

6. Owens, V.N., Albrecht, K.A., Muck, R.E. and Duke, S.H (1999) Protein degradation and fermentation characteristics of red clover and alfalfa silage harvested with varying levels of total nonstructural carbohydrates. Crop Sci., 39(6): 1873-1880.

7. Ke, W.C., Ding, W.R., Xu, D.M., Ding, L.M., Zhang, P., Li, F.D. and Guo, X.S. (2017) Effects of addition of malic or citric acids on fermentation quality and chemical characteristics of alfalfa silage. J. Dairy Sci., 100(11): 8958-8966.

8. Jayanegara, A., Ardani, V. and Sukria, H.A. (2019) Nutritional comparison between dried and ensiled indigofera, papaya and moringa leaves. J. Indones. Trop. Anim. Agric., [In press].

9. Girard, A.L., Bean, S.R., Tilley, M., Adrianos, S.L. and Awika, J.M. (2018) Interaction mechanisms of condensed tannins (proanthocyanidins) with wheat gluten proteins. Food Chem., 245: 1154-1162.

10. Jayanegara, A. and Palupi, E. (2010) Condensed tannin effects on nitrogen digestion in ruminants: A meta-analysis from in vitro and in vivo studies. Media Peternak., 33(3): 176-181.

11. Mezzomo, R., Paulino, P.V.R., Detmann, E., Valadares Filho, S.C., Paulino, M.F., Monnerat, J.P.I.S., Duarte, M.S., Silva, L.H.P. and Moura, L.S. (2011) Influence of condensed tannin on intake, digestibility, and efficiency of protein utilization in beef steers fed high concentrate diet. Livest. Sci., 141(1): 1-11.

12. Hymes-Fecht, U.C., Broderick, G.A., Muck, R.E. and Grabber, J.H. (2013) Replacing alfalfa or red clover silage with birdsfoot trefoil silage in total mixed rations increases production of lactating dairy cows. J. Dairy Sci., 96(1): 460-469.

13. Hoste, H., Torres-Acosta, J.F.J., Sandoval-Castro, C.A., Mueller-Harvey, I., Sotiraki, S., Louvandini, H., Thamsborg, S.M. and Terrill, T.H. (2015) Tannin-containing legumes as a model for nutraceuticals against digestive parasites in livestock. Vet. Parasitol., 212(1-2): 5-17.

14. Bhatta, R., Uyeno, Y., Tajima, K., Takenaka, A., Yabumoto, Y., Nonaka, I., Enishi, O. and Kurihara, M. (2009) Difference in the nature of tannins on in vitro ruminal methane and volatile fatty acid production and on methanogenic archaea and protozoal populations. J. Dairy Sci., 92(11): 5512-5522.

15. Jayanegara, A., Kreuzer, M. and Leiber, F. (2012) Ruminal disappearance of polyunsaturated fatty acids and appearance of biohydrogenation products when incubating linseed oil with alpine forage plant species in vitro. Livest. Sci., 147(1-3): 104-112.

16. Buccioni, A., Pauselli, M., Minieri, S., Roscini, V., Mannelli, F., Rapaccini, S., Lupi, P., Conte, G., Serra, A., Cappucci, A., Brufani, L., Ciucci, F. and Mele, M. (2017) Chestnut or quebracho tannins in the diet of grazing ewes supplemented with soybean oil: Effects on animal performances, blood parameters and fatty acid composition of plasma and milk lipids. Small Rum. Res., 153: 23-30.

17. Kamel, H.E.M., Al-Dobaib, S.N., Salem, A.Z.M., López, S. and Alaba, P.A. (2018) Influence of dietary supplementation with sunflower oil and quebracho tannins on growth performance and meat fatty acid profile of Awassi lambs. Anim. Feed Sci. Technol., 235: 97-104.

18. Kondo, M., Shimizu, K., Jayanegara, A., Mishima, T., Matsui, H., Karita, S., Goto, M. and Fujihara, T. (2016) Changes in nutrient composition and in vitro ruminal fermentation of total mixed ration silage stored at different temperatures and periods. J. Sci. Food Agric., 96(4): $1175-1180$

19. AOAC. (2005) Official Methods of Analysis. $18^{\text {th }}$ ed. AOAC International, Arlington, VA, USA

20. Van Soest, P.J., Robertson, J.B. and Lewis, B.A. (1991) Methods for dietary fiber, neutral detergent fiber, and nonstarch polysaccharides in relation to animal nutrition. J. Dairy Sci., 74(10): 3583-3597.

21. Licitra, G., Hernandez, T.M. and Van Soest, P.J. (1996) Standardization of procedures for nitrogen fractionation of 
ruminant feeds. Anim. Feed Sci. Technol., 57(4): 347-358.

22. Jayanegara, A., Dewi, S.P., Laylli, N., Laconi, E.B., Nahrowi, N. and Ridla, M. (2016) Determination of cell wall protein from selected feedstuffs and its relationship with ruminal protein digestibility in vitro. Media Peternak., 39(2): 134-140.

23. Theodorou, M.K., Williams, B.A., Dhanoa, M.S., McAllan, A.B. and France, J. (1994) A simple gas production method using a pressure transducer to determine the fermentation kinetics of ruminant feeds. Anim. Feed Sci. Technol., 48(3-4): 185-197.

24. Fievez, V., Babayemi, O.J. and Demeyer, D. (2005) Estimation of direct and indirect gas production in syringes: A tool to estimate short-chain fatty acid production that requires minimal laboratory facilities. Anim. Feed Sci. Technol., 123-124(1): 197-210.

25. Tilley, J.M.A. and Terry, R.A. (1963) A two-stage technique for the in vitro digestion of forage crops. Grass For. Sci., 18(2): 104-111.

26. Adesogan, A.T. and Salawu, M.B. (2002) The effect of different additives on the fermentation quality, aerobic stability and in vitro digestibility of pea/wheat bi-crop silages containing contrasting pea to wheat ratios. Grass For. Sci., 57(1): 25-32.

27. Deaville, E.R., Givens, D.I. and Mueller-Harvey, I. (2010) Chestnut and mimosa tannin silages: Effects in sheep differ for apparent digestibility, nitrogen utilization and losses. Anim. Feed Sci. Technol., 157(3-4): 129-138.

28. Chaikong, C., Saenthaweesuk, N., Sadtagid, D., Intapim, A. and Khotakham, O. (2017) Local silage additive supplementation on fermentation efficiency and chemical components of leucaena silage. Livest. Res. Rur. Dev., 29(6): Article \#114.

29. Hapsari, S.S., Suryahadi, S. and Sukria, H.A. (2016) Improvement on the nutritive quality of napier grass silage through inoculation of Lactobacillus plantarum and formic acid. Media Peternak., 39(2): 125-133.

30. González, L.A., Hoedtke, S., Castro, A. and Zeyner, A. (2012) Assessment of in vitro ensilability of jack bean (Canavalia ensiformis) and cowpea (Vigna unguiculata) grains, sole or mixed with sorghum (Sorghum bicolor) grains. Cuban J. Agric. Sci., 46(1): 55-62.

31. Oladosu, Y., Rafii, M.Y., Abdullah, N., Magaji, U., Hussin, G., Ramli, A. and Miah, G. (2016) Fermentation quality and additives: A case of rice straw silage. Bio. Med. Res. Int., 2016(13): 7985167.

32. Jonsson, A. (1991) Growth of Clostridium tyrobutyricum during fermentation and aerobic deterioration of grass silage. J. Sci. Food Agric., 54(4): 557-568.

33. Silanikove, N., Perevolotsky, A. and Provenza, F.D. (2001) Use of tannin-binding chemicals to assay for tannins and their negative post-ingestive effects in ruminants. Anim. Feed Sci. Technol., 91(1-2): 69-81.

34. Ding, W., Guo, X. and Ataku, K. (2013) Characterization of peptides in ensiled alfalfa treated with different chemical additives. Anim. Sci. J., 84(12): 774-781.

35. Jayanegara, A., Sujarnoko, T.U.P., Ridla, M., Kondo, M. and Kreuzer, M. (2019) Silage quality as influenced by concentration and type of tannins present in the material ensiled: A meta-analysis. J. Anim. Physiol. Anim. Nutr., [In press].

36. Getachew, G., Blümmel, M., Makkar, H.P.S. and Becker, K. (1998) In vitro gas measuring techniques for assessment of nutritional quality of feeds: A review. Anim. Feed Sci. Technol., 72(3-4): 261-281.

37. Krieg, J., Seifried, N., Steingass, H. and Rodehutscord, M. (2017) In situ and in vitro ruminal starch degradation of grains from different rye, triticale and barley genotypes. Animal, 11(10): 1745-1753.

38. Archimède, H., Sauvant, D. and Schmidely, P. (1997) Quantitative review of ruminal and total tract digestion of mixed diet organic matter and carbohydrates. Reprod. Nutr. Dev., 37(2): 173-189.

39. Bach, A., Calsamiglia, S. and Stern, M.D. (2005) Nitrogen metabolism in the rumen. J. Dairy Sci., 88(S): E9-E21.

40. Jayanegara, A., Togtokhbayar, N., Makkar, H.P.S. and Becker, K. (2009) Tannins determined by various methods as predictors of methane production reduction potential of plants by an in vitro rumen fermentation system. Anim. Feed Sci. Technol., 150(3-4): 230-237.

41. Sebata, A., Ndlovu, L.R. and Dube, J.S. (2011) Chemical composition, in vitro dry matter digestibility and in vitro gas production of five woody species browsed by Matebele goats (Capra hircus L.) in a semi-arid savanna, Zimbabwe. Anim. Feed Sci. Technol., 170(1-2): 122-125.

42. Huyen, N.T., Fryganas, C., Uittenbogaard, G., MuellerHarvey, I., Verstegen, M.W.A., Hendriks, W.H. and Pellikaan, W.F. (2016) Structural features of condensed tannins affect in vitro ruminal methane production and fermentation characteristics. J. Agric. Sci., 154(8): 1474-1487.

43. Min, B.R., McNabb, W.C., Barry, T.N. and Peters, J.S. (2000) Solubilization and degradation of ribulose-1,5-bisphosphate carboxylase/oxygenase (EC 4.1.1.39; Rubisco) protein from white clover (Trifolium repens) and Lotus corniculatus by rumen microorganisms and the effect of condensed tannins on these processes. J. Agric. Sci., 134(3): 305-317.

44. Jolazadeh, A.R., Dehghan-Banadaky, M. and Rezayazdi, K. (2015) Effects of soybean meal treated with tannins extracted from pistachio hulls on performance, ruminal fermentation, blood metabolites and nutrient digestion of Holstein bulls. Anim. Feed Sci. Technol., 203: 33-40.

45. Jayanegara, A., Goel, G., Makkar, H.P.S. and Becker, K. (2015) Divergence between purified hydrolyzable and condensed tannin effects on methane emission, rumen fermentation and microbial population in vitro. Anim. Feed Sci. Technol., 209: 60-68.

46. Tavendale, M.H., Meagher, L.P., Pacheco, D., Walker, N., Attwood, G.T. and Sivakumaran, S. (2005) Methane production from in vitro rumen incubations with Lotus peduculatus and Medicago sativa, and effects of extractable condensed tannin fractions on methanogenesis. Anim. Feed Sci. Technol., 123-124(1): 403-419.

47. Becker, P.M., van Wikselaar, P.G., Franssen, M.C.R., de Vos, R.C.H., Hall, R.D. and Beekwilder, J. (2014) Evidence for a hydrogen-sink mechanism of $(+)$ catechin-mediated emission reduction of the ruminant greenhouse gas methane. Metabolomics, 10(2): 179-189. 